\title{
Chinese University EFL Undergraduate Students' Perceptions towards EGAP Reading and Writing Courses
}

\author{
Ning $\mathrm{Du}^{1}$, Jianhua $\mathrm{Chen}^{2} \&$ Meihua $\mathrm{Liu}^{3}$ \\ ${ }^{1}$ Foreign Language Department, Beijing Union University, Beijing, China \\ ${ }^{2}$ College of Tourism, Beijing Union University, Beijing, China \\ ${ }^{3}$ Department of Foreign Languages \& Literatures, Tsinghua University, Beijing, China \\ Correspondence: Ning Du, Foreign Language Department, Beijing Union University, Beijing, 100101, China. \\ Tel: 86-10-64900240. E-mail: duning@buu.edu.cn
}

Received: July 12, 2016 Accepted: August 20, 2016 Online Published: August 22, 2016

doi: 10.5539/elt.v9n10p47 URL: http://dx.doi.org/10.5539/elt.v9n10p47

\begin{abstract}
The present study examined how undergraduate students from a prestigious Chinese university perceived the teaching and learning of English for general academic purposes (EGAP) reading and writing courses. Analyses of 951 questionnaires revealed that most participants generally (strongly) believed that learning general academic English was closely related to their major study, reported being motivated to learn general academic English, and expected to improve their academic English reading, writing, listening and speaking skills from EGAP courses. The study also showed that they had consensus about the requirements and teaching and learning foci of general academic English in spite of their concerns about academic English, and that students of more demanding and more academic EGAP courses tended to have a better understanding of general academic English. Based on the findings, some suggestions are discussed.
\end{abstract}

Keywords: English for general academic purposes, requirement, teaching and learning foci, major study

\section{Introduction}

As globalization goes on, English has become the predominant language of communication in all areas, including the academic field (Flowerdew, 1999). For example, an important criterion to assess the status of an institution of higher education, a scientist and a researcher in a certain area in the world nowadays is to count how many research articles they have published in international journals, most of which are written in English (Zhang et al., 2011). As China develops, there has been an increasing demand for trained professionals who are also proficient in English (Zhang, Zhang \& Liu, 2011). This is stipulated in the new College English Curriculum Requirement (2007) which places high demands on students' ability to use academic English. To meet these demands, increasingly more educators and researchers in China have been appealing for a reform of shifting the focus of EFL (English as a foreign language) teaching in college from English for general purposes to English for specific/academic purposes (ESP/EAP) (Cai, 2010; Cai \& Liao, 2010; Han, 2007; Zhang, 2005; Zhang et al., 2011). Under this situation, the university, a highly prestigious university in China where the present study was conducted, started to shift the teaching focus from English for general purposes to English for general academic purposes (EGAP) in recent years. As EGAP had been practiced continuously for several semesters to date, the present study aimed to examine how students perceived the teaching and learning of EGAP reading and writing courses in a highly prestigious university in Mainland China.

\section{Literature Review}

According to Hyland and Hamp-Lyons (2002), EAP is defined as "the linguistic, sociolinguistic and psycholinguistic description of English as it occurs in the contexts of academic study and scholarly exchange itself". As English is the dominant language in different tertiary settings, university students need to possess the communicative skills required to participate in an academic environment. Thus, courses in English for academic purposes (EAP) are provided to bridge the gap between secondary and tertiary expectations of academic discourse to promote the students' academic literacy up to graduation (Hyland, 2006; Hyland \& Hamp-Lyons, 2002).

Since EAP teaching and learning have been practiced, they have caught the attention of many researchers 
(Afshar \& Movassagh, 2016; Flowerdew, 1999; Harwood, 2014; Mazgutova \& Kormos, 2015). For example, to probe how SymbalooEDU was used in a PLE (personal learning environment) platform to support L2 learners of EAP (English for academic purposes), Harwood (2014) administered a need survey and a feedback survey to 306 undergraduate and graduate students. Analyses of the data revealed that students considered the software beneficial and convenient for EAP. However, the instructors should be aware of the role they play in guiding EAP learners to develop their PLEs when using such social media as SymbalooEDU. To investigate the perception of needs of Iranian EAP students with the current EAP education, Afshar and Movassagh (2016) recruited 831 students and 55 teachers to fill out a questionnaire. Among them, 40 students and 25 teachers completed a 6-question semi-structured interview. Data were also collected from classroom observations. The results revealed a significant difference among the needs specified by EAP syllabi, EAP teachers' and students' perception of needs. The EAP curricula, syllabi and materials were not designed by taking the students' needs into account. Most students believed they needed listening and speaking skills to take part in academic discussions, while teachers did not regard them as important needs. In order to examine the change of the lexical and syntactic characteristics in L2 learners' academic writing, Mazgutova and Kormos (2015) investigated two groups of EFL learners who took an intensive four-week course in the UK, with the first group consisting of 25 students of Chinese L1 background and the second group 14 undergraduate students whose English language proficiency was slightly lower than that of the former. Findings indicated that: (a) both groups of students demonstrated improvements in terms of lexical diversity; (b) as to syntax, the lower proficiency groups showed development with regard to the use of complex noun phrases and conditional clauses; (c) syntactic similarity was observed between both groups at the end of the course. In a study of a pedagogic model for EAP, Salter-Dvorak (2016) carried out an action research project at a UK university aimed at developing L2 students' argumentation by introducing an oral presentation between the first and second drafts of their writing. About $400 \mathrm{~L} 2$ students of 37 nationalities were divided into three groups based on their IELTS scores, with level one the lowest score and level three the highest. Students in the level two group completed questionnaires and data were collected from interviews and notes from staff meetings. The results indicated a difference between students' and lecturer's value orientation. The lecturers considered the oral presentation a good opportunity for the students to develop argumentation, while the latter regarded it as a performance-based evaluation. In addition, the lecturers paid much attention to argumentation in their feedback, while the students focused on accuracy in their revisions on drafts.

In Ro's (2016) study of the extensive reading (ER) approach in EAP context, 37 students of two classes in academic English language programs at an American university, responded to a 43-item reading motivation questionnaire and data were collected from classroom observations, interviews, and notes from debriefing sessions, casual talks and classroom materials. The results showed that the reading motivation of one class was enhanced while the reading amount of the other class was comparatively larger with less reading motivation increase. The students' motivation and their reading amount were affected by some specific reading practices (e.g. classroom activities) and inherent characteristics of extensive reading (e.g. reading for enjoyment). To explore the strategies students use in their own study context, McGrath et al. (2016) conducted a study in which 29 high proficiency L2 students of English were asked to keep a reading blog when reading at home. The results indicated that the students used different strategies when reading different texts and when assigned different tasks. Among a variety of reading strategies, connecting to short-term writing task was the most common strategy they employed. However, when realizing the misuse of some reading strategies, they did not tend to reuse successful strategies.

As reviewed, students had diverse perceptions towards the teaching and learning of EGAP and benefited differently thereupon. As EGAP teaching and learning has been increasingly practiced in China, it is important to examine how students perceive it as well. For this purpose, the present study aimed to investigate how students perceived the teaching and learning of EGAP in a highly prestigious university in Beijing, China. And the following questions are of particular interest:

(1) What are the students' attitudes towards EGAP reading and writing courses?

(2) What are the students' expectations and concerns about EGAP reading and writing courses?

\section{The Present Study}

\subsection{The Context}

The present study was conducted in a highly prestigious university which was one of the few institutions of higher education in Mainland China that had shifted their focus from teaching English for general purposes (EGP) to English for general academic purposes (EGAP) to undergraduate non-English major students. Based on 
a series of survey studies of students' needs in various disciplines, a careful examination of the university's development objective and the $i+1$ input theory (Krashen, 1982) and language learning principles (Ellis, 1994), a multi-channel, individualized, multi-level, and sub-serial English teaching and learning framework which shifts the focus of English teaching from EGP to EGAP to non-English majors at the university is formulated (Zhang et al., 2011).

As the core of English education at the university, EGAP courses are further divided into two groups: general academic English reading and writing (R\&W) courses 1-4 and listening and speaking (L\&S) courses 1-4. R\&W courses are designed according to genre, namely expository, argumentative, literature review and project-based reading and writing which are considered most common academic discourse genres; while L\&S courses are taught according to students' English proficiency levels which are determined by their placement test scores upon entering the university. The higher the level, the more challenging the course is.

Since the present study only focused on EGAP reading and writing courses, only these courses are described in this paper. Each academic English R\&W/or L\&S course has one meeting of 90 minutes with students per week during a 16-week semester. In addition to the common skills to be covered throughout all courses, each R\&W or L\&S course has its own specific focus. Expository R\&W course focuses on how to read and write expository essays effectively, elaborating on such exposition developing skills as thesis statement, definition, classification, process, exemplification, comparison and contrast, cause and effect and description; argumentative R\&W course aims to develop students' ability to read and write argumentative essays effectively, with a focus on such argument-developing skills as argument structure, use of reliable sources, cause and effect, comparison and effect, inference and deduction, clear flow of reasoning and avoidance of false arguments, emotional appeal and refutation; literature review R\&W course aims to foster students' ability to search for related literature, think critically and integrate ideas effectively into a literature review report; project-based $\mathrm{R} \& \mathrm{~W}$ course aims to lead students to writing up a real research paper based on a mini project step by step such as selecting a topic, doing literature review, designing the research, collecting and analyzing data, presenting the results, discussing the results and writing introductions, conclusions and abstracts.

In actual classroom teaching and learning, instructors of each course follow the same teaching syllabus, focus on text structure and understanding of texts, with integrated discussions of both writing and reading skills of the same specific genre (namely, expository, argumentative, literature review, projected-based reading and writing), and differences between academic English and informal English. Students of the same course have to read and practice writing extensively in that specific genre, expand their vocabulary, especially academic vocabulary via reading and writing, enhance their awareness and understanding of the features of academic English reading and writing of a specific genre.

\subsection{The Design}

\subsubsection{Participants}

Altogether 951 (677 male and 274 female) first- and second-year students who registered in the EGAP R\&W courses participated in the present study: 385, 275, 184 and 104 of them registered in expository, argumentative, literature review and project-based R\&W courses respectively. Of these participants, 901 (94.7\%) were Mainland Chinese and $50(5.3 \%)$ were international students from Hong Kong, Taiwan and other regions and countries; $63(6.4 \%), 517(54.4 \%), 57(6 \%), 136(14.3 \%), 70(7.4 \%), 27(2.8 \%)$ and $20(2.1 \%)$ were students of science, technology and engineering, social science and humanity, economics \& management, medicine and arts respectively.

\subsubsection{Instrument}

In order to examine students' attitudes towards the teaching and learning of EGAP, a 38-item 7-point Likert scale Attitudes towards EGAP (AEGAP) scale was developed with reference to Bruce (2011), Hyland (2006) and Jordan (1997), and Liu and Zhang (2015). The scale had four dimensions: general requirements for EGAP, teaching and learning foci of EGAP, self-perceived ability to learn EGAP, and the relation of EGAP to students' major study. We included three items about students' self-perceived ability to learn academic English because current research shows that positive self-beliefs may promote students' academic achievement (Simmons \& Blyth, 1987; Valentine, DuBois, \& Cooper, 2004). In addition, there were 4 open-ended questions about the students' self-perceived advantages and disadvantages and their expectations and concerns of the teaching and learning of EGAP reading and writing courses.

\subsubsection{Data Collection and Analysis}

The survey was administered to 25 intact classes of EGAP courses in the last week of an academic semester, 
which was answered in 10 minutes in a normal teaching class. Of 1037 collected questionnaires, 951 were valid for further analyses. The closed-ended items were subjected to factor analyses first and then ANOVA to examine the differences in the students' attitudes towards the teaching and learning of EGAP among students registering in different EGAP courses. The open-ended questions were subjected to thematic content analyses (Richards, 2009).

\section{Results and Discussion}

\subsection{Factor Analysis of the AEGAP}

A factor analysis with varimax rotation was run on the AEGAP to reveal its underlying components, which resulted in four subcomponents, as expected by the researchers (Table 1). The first AEGAP component (AEGAP1) included 18 items (items 15-32), which entailed the teaching and learning foci of EGAP and explained $42.9 \%$ of the total variance. Fourteen items (items 1-14) tapped the second AEGAP component (AEGAP2), which was concerned with general requirements for EGAP and accounted for $40.2 \%$ of the total variance. Three items were included in the third and fourth AEGAP components respectively, which involved the ability to learn EGAP (AEGAP3, items 33-35) and the relation of EGAP to students' major study (AEGAP4, items $36-38$ ) and explained $2.3 \%$ and $2.1 \%$ of the total variance respectively.

Table 1. Varimax rotated loadings for factor analysis of the AEGAP $(\mathrm{N}=951)$

\begin{tabular}{|c|c|c|c|c|}
\hline & AEGAP1 & AEGAP2 & AEGAP3 & AEGAP4 \\
\hline 1. Academic English has its own format. & & .557 & & \\
\hline 2. Academic English has its own way of expressing ideas. & & .648 & & \\
\hline 3. Academic English avoids plagiarism. & & .748 & & \\
\hline 4. Academic English requires accurate use of language. & & .769 & & \\
\hline 5. Academic English requires formal use of language. & & .760 & & \\
\hline 6. Academic English requires concise use of language. & & .687 & & \\
\hline 7. Academic English has a high requirement for logic. & & .776 & & \\
\hline 8. Academic English requires clear structure. & & .742 & & \\
\hline 9. Academic English requires ideas be adequately supported. & & .627 & & \\
\hline 10. Academic English requires ideas be clearly expressed. & & .647 & & \\
\hline 11. Academic English requires the thesis be clearly stated. & & .649 & & \\
\hline $\begin{array}{l}\text { 12. Academic English requires topics sentences of supporting } \\
\text { paragraphs be clearly expressed. }\end{array}$ & & .647 & & \\
\hline $\begin{array}{l}\text { 13. Academic English requires the content be closely related to } \\
\text { the thesis. }\end{array}$ & & .603 & & \\
\hline 14. Academic English requires extensive reading. & & .391 & & \\
\hline $\begin{array}{l}\text { 15. Academic English teaching and learning focus on } \\
\text { vocabulary. }\end{array}$ & .649 & & & \\
\hline 16. Academic English teaching and learning focus on grammar. & .807 & & & \\
\hline $\begin{array}{l}\text { 17. Academic English teaching and learning focus on } \\
\text { pronunciation. }\end{array}$ & .674 & & & \\
\hline $\begin{array}{l}\text { 18. Academic English teaching and learning focus on academic } \\
\text { work in English (e.g., assignment, research, etc.). }\end{array}$ & .482 & & & \\
\hline $\begin{array}{l}\text { 19. Academic English teaching and learning focus on } \\
\text { English-Chinese /Chinese-English translation. }\end{array}$ & .473 & & & \\
\hline $\begin{array}{l}\text { 20. Academic English teaching and learning focus on text } \\
\text { structure. }\end{array}$ & .281 & & & \\
\hline $\begin{array}{l}\text { 21. Academic English teaching and learning focus on } \\
\text { understanding of texts. }\end{array}$ & .245 & & & \\
\hline
\end{tabular}


22. Academic English teaching and learning focus on .314 developing the ability to produce academic English.

23. Academic English teaching and learning focus on .216 developing comprehensive ability to use English.

24. Academic English teaching and learning focus on academic English reading skills.

25. Academic English teaching and learning focus on academic $\quad .320$ English writing skills.

26. Academic English teaching and learning focus on academic English listening skills.

27. Academic English teaching and learning focus on academic English speaking skills.

28. Academic English teaching and learning focus on .218 developing the ability to read academic English.

29. Academic English teaching and learning focus on .458 developing the ability to write academic English.

30. Academic English teaching and learning focus on developing the ability to listen to academic English (e.g., talks, lectures and seminars, etc.).

31. Academic English teaching and learning focus on developing the ability to communicate orally in academic English (e.g., seminar discussions and conference presentations, etc.).

32. The assessment of academic English teaching and learning focuses on students' comprehensive ability to use English.

33. A person who is good at general English is easier to learn academic English.

34. Some people have a better sense of academic English.

35. I think I can learn academic English well.

36. It is necessary to learn academic English in college.

37. Academic English is closely related to my major study.

38. Students in my university are motivated to learn academic English.

Notes: AEGAP $=$ Attitudes towards English for General Academic Purposes.

AEGAP1 = the teaching and learning foci of EGAP; AEGAP2 = general requirements for EGAP.

AEGAP3 = the ability to learn EGAP; AEGAP4 = the relation of EGAP to students' major study.

As shown in Table 1, all the items within a component bore high loadings with that component, with a loading range of .216 to .807 , with most loadings higher than .50 . Meanwhile, the four components were all highly positively correlated with one another, with a coefficient range of .321 to $.717(\mathrm{p} \leq .01)$, as reported in Table 2 .

Table 2. Correlations among the four components of AEGAP

\begin{tabular}{llll}
\hline & AEGAP2 & AEGAP3 & AEGAP4 \\
\hline AEGAP1 & $.717^{* *}$ & $.373^{* *}$ & $.322^{* *}$ \\
AEGAP2 & 1 & $.325^{* *}$ & $.390^{* *}$ \\
AEGAP3 & & 1 & $.321^{* *}$ \\
\hline
\end{tabular}

Note: $* *=\mathrm{p} \leq .01$. 


\subsection{Students'Attitudes towards EGAP}

As previously described, all the descriptors of each item were assigned values of 1-7 respectively. Consequently, a score of 6-7 on an item is implicative of strong agreement, a score of 4-6 means agreement, and a score of below 4 suggests (strong) disagreement.

\subsubsection{General Requirements of EGAP}

As shown in the Appendix, the mean for the 14 AEGAP2 items ranged from 5.29 to 5.99, far exceeding the item midpoint 4. This suggests that more than half of the participants (strongly) agreed that general academic English had its own requirements, such as its own way of expressing ideas (item $2, \mathrm{~m}=5.67$ ), avoiding plagiarism (item $3, \mathrm{~m}=5.97$ ), accurate use of language (item $4, \mathrm{~m}=5.89$ ), clear statement of the thesis (item $11, \mathrm{~m}=5.88$ ), adequate use of evidence (item $9, \mathrm{~m}=5.79$ ) and high demand for logic (item 7, $\mathrm{m}=5.99$ ).

\subsubsection{Teaching and Learning Foci of EGAP}

The Appendix shows that the participants scored from 4.42 to 5.75 on the 18 AEGAP1 items, all above the item midpoint 4, meaning that more than half of the participants (strongly) endorsed the teaching and learning foci of EGAP. For example, the participants generally (strongly) believed that general academic English teaching and learning should focus on text structure (item $20, \mathrm{~m}=5.48$ ), understanding of texts (item $21, \mathrm{~m}=5.63$ ), the ability to produce (item 22, $\mathrm{m}=5.57$ ) and use (item 23, $\mathrm{m}=5.67$ ) academic English, reading (item $24, \mathrm{~m}=5.67$ ), writing (item $25, \mathrm{~m}=5.56$ ), listening (item $26, \mathrm{~m}=5.33$ ) and speaking (item $27, \mathrm{~m}=5.43$ ) skills, and developing the ability to read (item $28, \mathrm{~m}=5.70$ ), write (item $29, \mathrm{~m}=5.75$ ), listen to (item $30, \mathrm{~m}=5.64$ ) and communicate orally (item $31, \mathrm{~m}=5.62$ ) in general academic English. Comparatively speaking, fewer students (strongly) agreed that general academic English teaching and learning should focus on vocabulary (item 15, $\mathrm{m}=$ 4.89), grammar (item $16, \mathrm{~m}=4.42$ ), and pronunciation (item $17, \mathrm{~m}=4.59$ ), while the means for all the other AEGAP items exceeded 5.00.

\subsubsection{Ability to Learn EGAP}

The Appendix shows that the participants scored from 5.66 to 5.71 on the three AEGAP3 items, well above the item midpoint 4.00. This indicates that most participants (strongly) held that people good at general English were easier to learn general academic English (item 33, $\mathrm{m}=5.69$ ), that some people had a better sense of general academic English (item 34, $\mathrm{m}=5.66$ ), and that they themselves could learn general academic English well (item $35, \mathrm{~m}=5.71)$.

\subsubsection{Relation of EGAP to Students' Major Study}

The Appendix reveals that the participants scored from 5.22 to 5.95 on the three AEGAP4 items, all exceeding the item midpoint 4.00 , meaning that the participants (strongly) believed that learning general academic English was closely related to their major study. To them, it was necessary to learn general academic English in college (item $36, \mathrm{~m}=5.95$ ), general academic English was closely related to my major study (item $37, \mathrm{~m}=5.58$ ), and the students in their university were motivated to learn academic English (item 38, $\mathrm{m}=5.22$ ).

Meanwhile, ANOVA results (Table 3) revealed that significant differences existed in the students of different EGAP courses in their attitudes towards EGAP. As summarized in Table 3, students of expository and argumentative $\mathrm{R} \& \mathrm{~W}$ courses believed significantly less than did their counterparts of literature review and project-based R\&W courses that general academic English had its own requirements (AEGAP2). Nevertheless, no significant difference was found between students of expository and argumentative R\&W courses or between those of literature review and project-based R\&W courses. It was exactly the same with the teaching and learning foci of EGAP (AGEPA1). Students of literature review R\&W course agreed significantly more than did their peers of the other three R\&W courses with the idea that learning general academic English was closely related to their major study (AEGAP4). No significant difference was identified between any two groups of students in terms of students' ability to learn general academic English (AEGAP3). 
Table 3. ANOVA results of the AGEP

\begin{tabular}{llllllll}
\hline & F & $p$ & \multicolumn{3}{l}{ Mean for each course group } & Location of sig. difference $(\mathrm{p}=.05)$ \\
\cline { 3 - 7 } & & & 1 & 2 & 3 & 4 & \\
\hline AEGAP1 & 6.26 & .000 & 28.26 & 28.96 & 30.80 & 29.78 & $1 \& 3,1 \& 4,2 \& 3,2 \& 4,3 \& 4$ \\
AEGAP2 & 20.68 & .000 & 44.46 & 45.47 & 48.93 & 48.22 & $1 \& 3,1 \& 4,2 \& 3,2 \& 4$ \\
AEGAP3 & .624 & .600 & 16.98 & 16.99 & 17.42 & 16.93 & $/$ \\
AEGAP4 & 7.42 & .000 & 16.28 & 16.61 & 17.97 & 16.86 & 3 \& the others \\
\hline
\end{tabular}

Notes: 1 = expository R\&W course; 2 = argumentative R\&W course.

3 = literature review $\mathrm{R} \& \mathrm{~W}$ course; 4 = project-based $\mathrm{R} \& \mathrm{~W}$ course.

\subsection{Expectations and Concerns about EGAP}

When asked about their strengths and weaknesses in learning general academic English, students of different $\mathrm{R} \& \mathrm{~W}$ courses generally voiced similar answers, as summarized in Tables 4 and 5 .

As shown in Table 4, students of different R\&W courses reported having similar strengths in learning general academic English, such as being interested in, willing and motivated to learn English, having a good sense of logic and language, reading extensively, and having access to rich academic English learning resources. As reported by the participants, students of certain disciplines of the university were required to read literature in English and/or had to take major courses in English, which motivated (greatly) them to learn general academic English well. Meanwhile, the rich academic English learning resources provided by the university (e.g., library resources, lectures and talks organized by different disciplines, etc.) offered them a self-learning platform and indirectly inspired their interest in general academic English, as discussed in $\mathrm{He}$ (2003).

Table 4. Strengths in learning general academic English

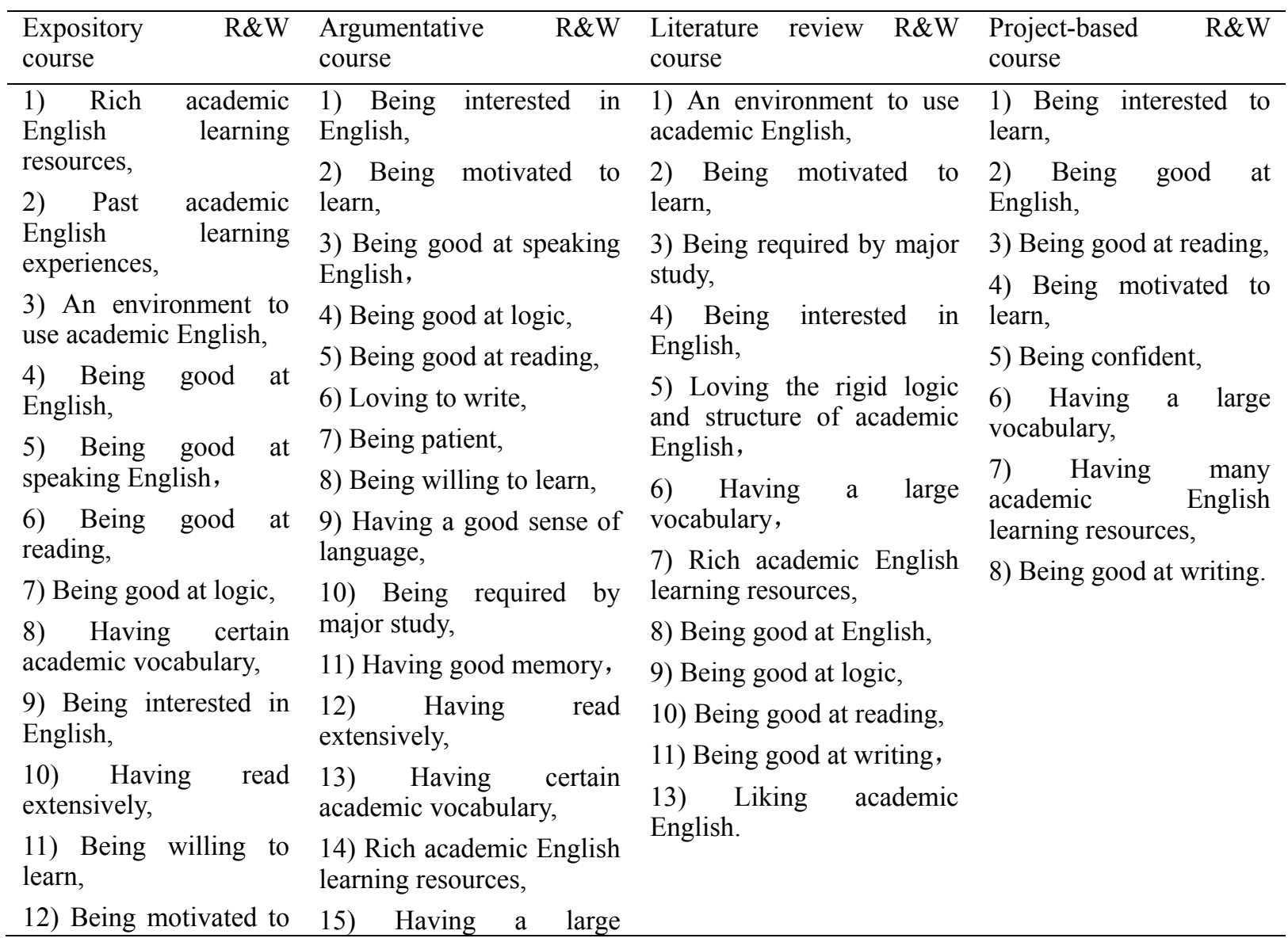




\section{learn,}

13) Being willing to revise repeatedly,

14) Being confident in English learning,

15) Being good at English writing,

16) Being persistent in English learning,

17) Being good at understanding text structures,

18) Having a good sense of language,

19) Major courses being taught in English.

\section{vocabulary,}

16) Having many opportunities to use academic English.

Likewise, their weaknesses were similar as well. As noted in Table 5, the participants reported having such weaknesses in learning general academic English as being poor in English, having a small vocabulary, having no motivation and/or time to learn English, being poor in reading, speaking, listening and writing, being poor in logic and lack of practice.

Table 5. Weaknesses in learning general academic English

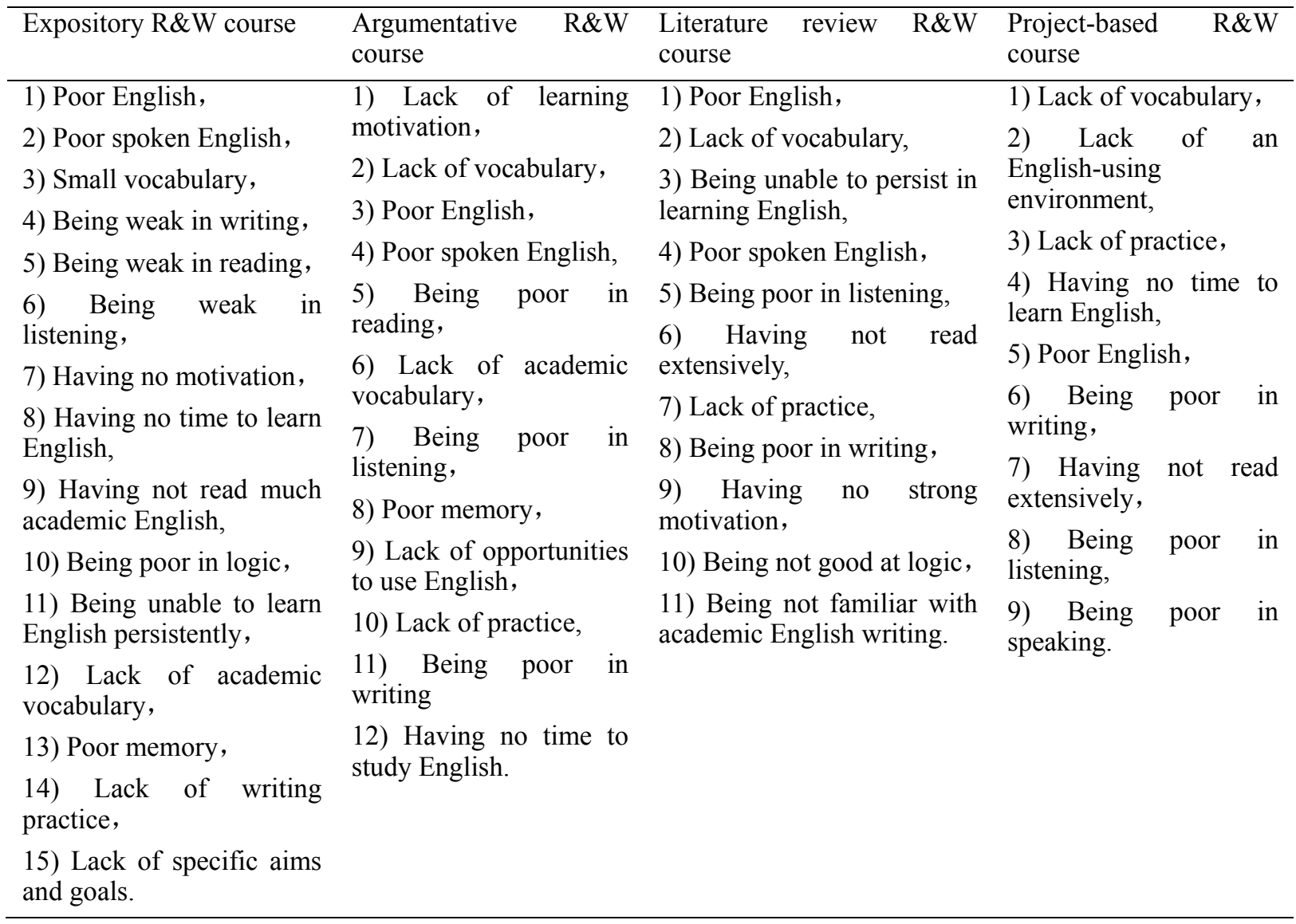

Consequently, they expected the following from EGAP courses: developing their ability to read, especially the literature related to their major study, to communicate ideas orally to others in public, listen to and understand 
lectures and talks and to write satisfactory academic papers, expanding their vocabulary, improving their English proficiency, extending their visions, becoming familiar with the principles and formats for writing academic English and the differences between academic English and general English, and strengthening the relation between academic English and their major study. As reported by the participants, they expected to learn how to read more effectively, especially the literature related to their major study, which was often required by the instructors of major courses. They hoped to be able to "locate and understand literature, evaluate ideas, incorporate different ideas and form those of their own, and express their ideas clearly in academic English in written and oral forms" (Shuo, Literature Review R\&W course). Therefore, they also expected that they could learn from EGAP courses how to have a better understanding of the text structure when reading and plan their text when writing. Generally speaking, they reported that, among the four skills of general academic English, speaking $(350 / 36.8 \%)$ was the most difficult, followed by writing $(315 / 33.1 \%)$, reading $(113 / 11.9 \%)$ and listening (295/31\%) respectively.

Table 6. Expectations of EGAP courses

\begin{tabular}{|c|c|c|c|}
\hline Expository R\&W course & $\begin{array}{l}\text { Argumentative } \\
\text { course }\end{array}$ & $\begin{array}{l}\text { Literature } \\
\text { R\&W course }\end{array}$ & Project-based $R \& W$ course \\
\hline $\begin{array}{l}\text { 1) To improve reading } \\
\text { ability, especially } \\
\text { literature reading ability, } \\
\text { 2) To improve the ability } \\
\text { to speak English in the } \\
\text { public, } \\
\text { 3) To improve the ability } \\
\text { to understand lectures, } \\
\text { talks and speeches, } \\
\text { 4) To improve the ability } \\
\text { to express ideas properly, } \\
\text { 5) To improve writing } \\
\text { ability, } \\
\text { 6) To improve English, }\end{array}$ & $\begin{array}{l}\text { 1) To improve the ability } \\
\text { to communicate in } \\
\text { academic English orally, } \\
\text { 2) To improve the ability } \\
\text { to write academic } \\
\text { English papers, } \\
\text { 3) To help major study, } \\
\text { 4) To improve reading } \\
\text { ability, especially } \\
\text { literature reading ability, } \\
\text { 5) To improve the ability } \\
\text { to listen to and } \\
\text { understand lectures, talks } \\
\text { and speeches, } \\
\text { 6) To improve the } \\
\text { comprehensive ability to } \\
\text { use English, the } \\
\text { 7) To strengthen the } \\
\text { relation between } \\
\text { academic English } \\
\text { learning and major study, } \\
\text { 8) To extend visions, } \\
\text { 9) To become familiar } \\
\text { with academic English } \\
\text { writing. }\end{array}$ & 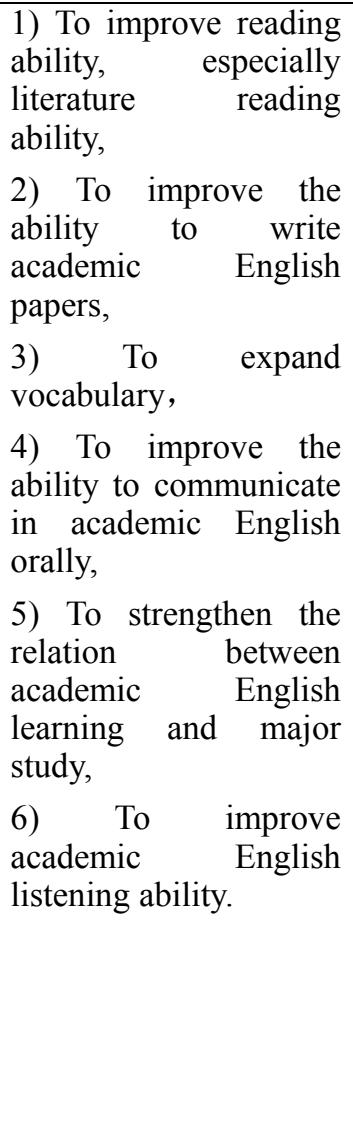 & $\begin{array}{l}\text { 1) To strengthen the relation } \\
\text { between academic English } \\
\text { learning and major study, } \\
\text { 2) To improve the ability to } \\
\text { communicate in academic } \\
\text { English orally, } \\
\text { 3) To improve reading } \\
\text { ability, especially literature } \\
\text { reading ability, } \\
\text { 4) To become familiar with } \\
\text { academic English writing. } \\
\text { 5) To improve the } \\
\text { comprehensive ability to use } \\
\text { English, } \\
\text { 6) To improve the ability to } \\
\text { write academic English } \\
\text { papers, } \\
\text { 7) To expand vocabulary, } \\
\text { 8) To improve the ability to } \\
\text { speak English in the public, } \\
\text { 9) To improve the ability to } \\
\text { understand lectures, talks } \\
\text { and speeches, } \\
\text { 10) To be able to use } \\
\text { English freely in all } \\
\text { academic activities. }\end{array}$ \\
\hline
\end{tabular}

Meanwhile, the participants of all R\&W courses reported having some concerns about learning general academic English, as displayed in Table 7. They worried about having difficulty understanding texts and literature related to their major study, not having enough time to study English, not being able to improve their English (including speaking, listening, reading and writing) fast and satisfactorily. They were not sure of the differences between general English and general academic English or what general academic English was like. Thus, they also worried about not being able to cite sources appropriately or think and write in the mainstream style. Meanwhile, they were concerned with how to relate academic English to general English and their major study. They hoped that they could improve their general English proficiency as well while learning general academic English. 
Table 7. Concerns about learning general academic English

\begin{tabular}{|c|c|c|c|}
\hline$R \& W$ course & itative $R \& W$ course & $\begin{array}{l}\text { Literature } \\
\text { R\&W course }\end{array}$ & $\begin{array}{l}\text { Project-based } \\
\text { course }\end{array}$ \\
\hline $\begin{array}{l}\text { 1) Having difficulty } \\
\text { reading, especially }\end{array}$ & $\begin{array}{l}\text { 1) How to learn aca } \\
\text { English? }\end{array}$ & to $\mathrm{im}$ & 1) Having dif \\
\hline ne & 2) How to write better & 2) Not having enough & $\begin{array}{l}\text { general English to } \\
\text { academic English, }\end{array}$ \\
\hline English on ace & & & $\begin{array}{l}\text { English } \\
\text { ific? }\end{array}$ \\
\hline $\begin{array}{l}\text { English learning, } \\
\text { 3) Having little time for } \\
\text { English learning, }\end{array}$ & $\begin{array}{l}\text { Engl } \\
\text { 4) } \mathrm{H} \\
\text { relate }\end{array}$ & $\begin{array}{ll}\text { 3) How to expand } \\
\text { academic } & \text { English } \\
\text { vocabulary? } & \end{array}$ & $\begin{array}{l}\text { discipline specific? } \\
\text { 3) Do grammar and } \\
\text { sentence structure }\end{array}$ \\
\hline $\begin{array}{l}\text { nable to persist in } \\
\text { gglish, }\end{array}$ & 5) What is academic English? & $\begin{array}{l}\text { 4) How to improve } \\
\text { academic English }\end{array}$ & $\begin{array}{l}\text { matter in acade } \\
\text { English? }\end{array}$ \\
\hline $\begin{array}{l}\text { 5) What is academic } \\
\text { English? }\end{array}$ & $\begin{array}{l}\text { 6) How to improve academic } \\
\text { English? }\end{array}$ & $\begin{array}{l}\text { listening, speaking, } \\
\text { reading and writing? }\end{array}$ & $\begin{array}{l}\text { 4) How to cite more } \\
\text { literature? }\end{array}$ \\
\hline $\begin{array}{l}\text { 6) How to relate academic } \\
\text { English to major study? }\end{array}$ & & $\begin{array}{ll}5) \mathrm{H} \\
\text { effec }\end{array}$ & $\begin{array}{l}\mathrm{w} \text { to improve } \\
\mathrm{g} \text { ability? }\end{array}$ \\
\hline $\begin{array}{l}\text { 7) How is academic English } \\
\text { different from general } \\
\text { English? }\end{array}$ & $\begin{array}{l}\text { ng no time to learn } \\
\text { erences in thinking }\end{array}$ & $\begin{array}{l}\text { 6) How to relate } \\
\text { academic English to } \\
\text { major study? }\end{array}$ & $\begin{array}{l}\text { 6) Is it possible to } \\
\text { improve general } \\
\text { English ability as well }\end{array}$ \\
\hline $\begin{array}{l}\text { 8) Differences in thinking } \\
\text { style between the Chinese }\end{array}$ & & $\begin{array}{l}\text { 12) How is academic } \\
\text { English different }\end{array}$ & $\begin{array}{l}\text { when learning } \\
\text { academic English? }\end{array}$ \\
\hline and the westerners, & $\begin{array}{l}\text { 10) How to improve reading } \\
\text { ability, especially literature }\end{array}$ & $\begin{array}{l}\text { from } \\
\text { English? }\end{array}$ & $\begin{array}{l}\text { 7) How to relate } \\
\text { academic English to }\end{array}$ \\
\hline $\begin{array}{l}\text { 9) How to expand } \\
\text { vocabulary effectively? }\end{array}$ & & 13) How to & \\
\hline $\begin{array}{l}\text { 10) How to improve } \\
\text { listening and speaking } \\
\text { abilities effectively? }\end{array}$ & $\begin{array}{l}\text { 11) How to improve writing } \\
\text { ability? } \\
\text { 12) How to express }\end{array}$ & $\begin{array}{ll}\text { academic } & \text { English } \\
\text { effectively? } & \end{array}$ & $\begin{array}{l}\text { 8) How to learn } \\
\text { academic } \\
\text { effectively? }\end{array}$ \\
\hline ow to & & & $\begin{array}{l}\text { 9) What is academic } \\
\text { English? }\end{array}$ \\
\hline & $\begin{array}{l}\text { different from general } \\
\text { English? }\end{array}$ & & $\begin{array}{l}\text { 10) How is academic } \\
\text { English different from } \\
\text { general English? }\end{array}$ \\
\hline
\end{tabular}

\section{Discussion}

As expected, most participants (strongly) believed that learning general academic English was closely related to their major study, reported being motivated to learn general academic English, and expected to improve their general academic English reading, writing, listening and speaking skills (e.g., the ability to understand literature, talks and lectures, and communicate in academic English in written and oral forms, etc.) from EGAP courses. This is largely consistent with the view held by many researchers and educators (Cai, 2010; Cai \& Liao, 2010; Han, 2007; Zhang, 2005; Zhang et al., 2011) and further confirms the necessity of the reform (Zhang et al., 2011).

As revealed in the present study, most participants agreed that academic English had its own requirements such as avoiding plagiarism, accurate and concise use of language, and being well-structured. They also endorsed that the teaching and learning of academic English should focus on text structure, understanding of ideas, developing the abilities to read, write, understand and speak academic English effectively, with less focus on grammar and vocabulary. These reported attitudes are generally consistent with, as expected, the objectives of the EGAP courses and the aim of the reform. This indicates that the reformed English teaching at the university helped students basically realize what was required for (general) academic English and what they were expected to achieve in learning academic English. Nevertheless, as reported by the participants (Table 7), many students were still not sure what (general) academic English was and how it was different from general English and related to their major study. This suggests that more work is needed for EGAP course instructors who should clarify to their students' concepts about (general) academic English and its relationship with general English and major study. Meanwhile, it is necessary for students to take the initiative to read academic English as much as 
possible, especially literature related to their major study, to have a better understanding of what academic English is like and what it is required in their major study.

In addition, the present study found that students of expository and argumentative R\&W courses (1-2) believed significantly less than did their counterparts of literature review and project-based R\&W courses (3-4) in terms of specific requirements and teaching and learning foci of academic English, while no significant difference was found between students of expository and argumentative R\&W courses or between those of literature review and project-based R\&W courses. This implies that the more demanding and more academic an EGAP course was, the better the students understood academic English, lending support to the researcher's belief that (general) academic English learning is also a progressive process.

Meanwhile, although many participants in the present study reported being interested in and motivated to learn general academic English and having access to many academic English learning resources as it was required by their major study, some participants reported having no motivation and/or time to learn English and lacking practice. This suggests that the teaching and learning of EGAP also needs to be individualized and cater to students' specific needs. At the same time, it may be helpful to clearly demonstrate to all students the importance of (general) academic English.

Finally, since the teaching and learning of EGAP has been just recently practiced, more research is called for to examine both students' and teachers' perceptions of general academic English, the effectiveness of the new practices, discipline-specific needs for (general) academic English, and so on. Thus the teaching and learning of EGAP can better satisfy students' needs as well as the university's objectives.

\section{Conclusion}

The present study examined how undergraduate students from a prestigious university in China perceived the teaching and learning of EGAP, which revealed some insightful findings. Generally speaking, most participants (strongly) believed that learning general academic English was closely related to their major study, reported being motivated to learn general academic English, and expected to improve their (general) academic English reading, writing, listening and speaking skills from EGAP courses. They had consensus about the requirements and teaching and learning foci of general academic English, although they had some concerns about it as well. Meanwhile, the study showed that students of more demanding and more academic EGAP courses tended to have a better understanding of (general) academic English.

\section{References}

Afshar, H. S., \& Movassagh, H. (2016). EAP education in Iran: Where does the problem lie? Where are we heading. Journal of English for Academic Purposes, 22, 132-151. http://dx.doi.org/10.1016/j.jeap.2016.04.002

Bruce, I. (2011). Theory and concepts of English for academic purposes. NY: Palgrave Macmillan.

Cai, J. (2004). ESP and the direction of China's college English teaching. Foreign Language World, 2, 22-28.

Cai, J. (2009). From uniform to individualized-A review of 30 year college English education. China University Teaching, 3, 82-85.

Cai, J. (2010). Factors affecting the shift of the focus of college English teaching in China. Foreign Languages Research, 2, 40-45.

Cai, J., \& Liao, L. (2010). EAP vs. ESP-The orientation of college English. Foreign Language Education, 6, 47-50.

College English Curriculum Requirement. (2007). Beijing: Tsinghua University Press.

Dai, W. (2001). On further improving English language learning in China-Suggestions and consideration. Foreign Languages and Their Teaching, 7, 1-2.

Ellis, R. (1994). The study of second language acquisition. Oxford: Oxford University Press.

Flowerdew, J. (1999). Writing for scholarly publication in English: The case of Hong Kong. Journal of Second Language Writing, 8(2), 243-264. http://dx.doi.org/10.1016/S1060-3743(99)80125-8

Han, J. (2007). EAP: College English education reform and bilingual teaching. Higher Education Exploration, 6, 24-25.

Harwood, C. (2014). Personal learning environments: using SymbalooEDU in learning English for academic purposes. E.S.P. Today, 2(2), 199-215. 
He, L. (2003). Self-learning and the ability to self-learn. Foreign Language Teaching and Research, 4, 287-289.

Hyland, K. (2006). English for academic purposes: An advanced resource book. New York: Routledge. http://dx.doi.org/10.1016/j.jeap.2005.11.004

Hyland, K., \& Hamp-Lyons, L. (2002). EAP: issues and directions. Journal of English for Academic Purposes, 1(1), 1-12. http://dx.doi.org/10.1016/S1475-1585(02)00002-4

Jordan, R. R. (1997). English for academic purposes: A guide and resource book for teachers. Cambridge: Cambridge University Press. http://dx.doi.org/10.1017/CBO9780511733062

Krashen, S. (1982). Principles and practice in second language acquisition. Oxford: Pergamon.

Liu, M., \& Zhang, W. (2015). The Shifting Focus of English Education for Non-English Major Students: Practices and Reforms at Tsinghua University in China. In L.-T. Wong, \& A. Dubey-Jhaveri (Eds.), English language education in a global world: Practices, issues and challenges. New York: Nova Publication.

Mazgutova, D., \& Kormos, J. (2015). Syntactic and lexical development in an intensive English for Academic Purposes programme. Journal of Second Language Writing, 29, 3-15. http://dx.doi.org/10.1016/j.jslw.2015.06.004

McGrath, L., Berggren, J., \& Mezek, S. (2016). Reading EAP: Investigating high proficiency L2 university students' strategy use through reading blogs. Journal of English for Academic Purposes, 22, 152-164. http://dx.doi.org/10.1016/j.jeap.2016.03.003

Ro, E. (2016). Exploring teachers' practices and students' perceptions of the extensive reading approach in EPA reading classes. Journal of English for Academic Purposes, 22, 32-41. http://dx.doi.org/10.1016/j.jeap.2016.01.006

Richards, L. (2009). Handling qualitative data. Thousand Oaks, CA: Sage.

Salter-Dvorak, H. (2016). Learning to argue in EAP: Evaluating a curriculum innovation from the inside. Journal of English for Academic Purposes, 22, 19-31. http://dx.doi.org/10.1016/j.jeap.2015.12.005

Simmons, R. G., \& Blyth, D. A. (1987). Moving into adolescence: The impact of pubertal change and social context. Hawthorne, NY: Aldine De Gruyter.

Valentine, J. C., DuBois, D. L., \& Cooper, H. (2004). The relation between self-beliefs and academic achievement: A meta-analytic review. Educational Psychologist, 39(2), 111-133. http://dx.doi.org/10.1207/s15326985ep3902_3

Wang, H., \& Wang, T. (2003). Interfaces between bilingual teaching and EFL teaching. Foreign Language World, 1, 26-31.

Xia, J. (2003). Contemporary foreign language curriculum design and practice. Shanghai: Shanghai Foreign Language Education Press.

Zhang, J. (2005). Specialization of public English teaching and publicness of specialized English teaching. Foreign Languages and Their Teaching, 11, 28-31.

Zhang, W., Zhang, W., \& Liu, M. (2011). The shift from general to academic English teaching and learning. Foreign Languages Research, 5, 11-14.

Appendix. Means and Standard Deviations of AEGAP Items ( $\mathrm{N}=951)$

\begin{tabular}{lll}
\hline AEGAP items & Mean & SD \\
\hline 1. Academic English has its own format. & 5.29 & 1.33 \\
2. Academic English has its own way of expressing ideas. & 5.67 & 1.20 \\
3. Academic English avoids plagiarism. & 5.97 & 1.08 \\
4. Academic English requires accurate use of language. & 5.89 & 1.04 \\
5. Academic English requires formal use of language. & 5.73 & 1.15 \\
6. Academic English requires concise use of language. & 5.58 & 1.23 \\
7. Academic English has a high requirement for logic. & 5.99 & 1.03 \\
8. Academic English requires clear structure. & 5.91 & 1.07 \\
\hline
\end{tabular}


9. Academic English requires ideas be adequately supported.

10. Academic English requires ideas be clearly expressed.

11. Academic English requires the thesis be clearly stated.

12. Academic English requires topics sentences of supporting paragraphs be clearly expressed.

13. Academic English requires the content be closely related to the thesis.

14. Academic English requires extensive reading.

15. Academic English teaching and learning focus on vocabulary.

16. Academic English teaching and learning focus on grammar.

17. Academic English teaching and learning focus on pronunciation.

18. Academic English teaching and learning focus on academic work in English (e.g., 5.05 assignment, research, etc.).

19. Academic English teaching and learning focus on English-Chinese /Chinese-English translation.

20. Academic English teaching and learning focus on text structure.

21. Academic English teaching and learning focus on understanding of texts.

22. Academic English teaching and learning focus on developing the ability to produce academic English.

23. Academic English teaching and learning focus on developing comprehensive ability to use English.

24. Academic English teaching and learning focus on academic English reading skills.

25. Academic English teaching and learning focus on academic English writing skills.

26. Academic English teaching and learning focus on academic English listening skills.

27. Academic English teaching and learning focus on academic English speaking skills.

28. Academic English teaching and learning focus on developing the ability to read academic English.

29. Academic English teaching and learning focus on developing the ability to write academic English.

30. Academic English teaching and learning focus on developing the ability to listen to academic English (e.g., talks, lectures and seminars, etc.).

31. Academic English teaching and learning focus on developing the ability to communicate orally in academic English (e.g., seminar discussions and conference presentations, etc.).

32. The assessment of academic English teaching and learning focuses on students' 5.7 comprehensive ability to use English.

33. A person who is good at general English is easier to learn academic English.

34. Some people have a better sense of academic English.

5.712 .80

35. I think I can learn academic English well.

$5.95 \quad 1.18$

36. It is necessary to learn academic English in college.

$5.58 \quad 1.38$

37. Academic English is closely related to my major study.

5.22

\section{.09}

$5.86 \quad 1.06$

$5.88 \quad 1.05$

$5.83 \quad 1.06$

$5.77 \quad 1.14$

$5.49 \quad 1.29$

$4.89 \quad 1.46$

1.421

$59 \quad 1.51$

1.39

1.37

$5.48 \quad 1.24$

$5.63 \quad 1.13$

$5.57 \quad 1.20$

5.67

$5.67 \quad 1.17$

$5.56 \quad 1.22$

$5.33 \quad 1.32$

$5.43 \quad 1.29$

$5.70 \quad 1.16$

$5.75 \quad 1.14$

$5.64 \quad 1.19$

1.62

38. Students in my university are motivated to learn academic English.

\section{Copyrights}

Copyright for this article is retained by the author(s), with first publication rights granted to the journal.

This is an open-access article distributed under the terms and conditions of the Creative Commons Attribution license (http://creativecommons.org/licenses/by/4.0/). 